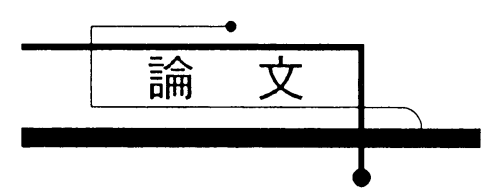

\title{
大口径管内気液二相流の界面抗力モデルと数值解析 ${ }^{*}$
}

\author{
Interfacial Drag Model and Numerical Analysis for Gas-Liquid Two-Phase Flow \\ in a Large Diameter Pipe
}

沈 秀 中**

SHEN Xiuzhong

\author{
三 島 嘉一郎*** \\ MISHIMA Kaichiro
}

\author{
中 村 秀 夫 $^{\dagger}$ \\ NAKAMURA Hideo
}

\begin{abstract}
As the two-phase flow regime evolves from bubbly to slug flows along the flow direction in a vertical large diameter pipe, the void fraction increases first in the bubbly flow region, then decreases in the transitional region, and finally increases again in the slug flow region. The $N$-shaped profile of void fraction was numerically analyzed by using the one-dimensional two-fluid model. Its interfacial drag model was modified by including constitutive equations of $C_{0}$ and $V_{g j}$ developed by Shen et al. [2] for evolving two-phase flow from bubbly to slug flows in a large diameter pipe. The numerical calculation predicted well the $N$-shaped profile of the measured axial void fraction distribution from the present experiments. The predicted average gas and liquid velocities indicated that the average gas velocity increased significantly and the average liquid velocity decreased slightly when the void profile is $N$-shaped one. The phenomenon can be attributed to the formation and development of large bubbles of pipe size.
\end{abstract}

Keywords: Large diameter pipe, Flow regime transition from bubbly to slug flow, Interfacial drag model, Two-fluid model, Numerical calculation

\section{1. 緒 言}

大口径管内気液二相流は原子カプラントに数 多く存在し、プラントの運転特性、効率、経済性 及び安全性に深く関連している。例えば、軽水型 動力炉においては、事故時の炉心出力変化と炉心 冷却の支配的要因となり、沸騰水型軽水炉

（BWR）においては事故時のみならず通常運転 時においても BWR 不安定のように炉心特性に大 きな影響を及ぼす原因となっている。

原子炉安全解析に不可欠な気液二相流研究で は、実験の容易さから主に通常口径管が用いられ てきた。近年、原子炉許認可用シミュレーション

\begin{abstract}
コードに用いられている物理モデルのスケーラ
ビリティが問題となっており、管径が $10 \mathrm{~cm}$ を超 える大口径管の場合[1]には、流れの様相が一変し、 多次元性や未発達性が顕著に現れ、従来の通常口 径管の知見に基づく二相流構成方程式では、原子 炉等大規模システムの熱水力現象を精度良く再 現できないことも考えられる。従って、大口径管 内の多次元気液二相流に対して、データベースの 構築、構成方程式の整備及び二流体モデルの数值 計算法の検証が、現在、原子炉熱水力分野におい て急務となっている。

本研究の大口径管内スラグ流は、テイラー気泡
\end{abstract}

\footnotetext{
* 2010.11.26 受付

** 京都大学原子炉実験所 $\bar{T} 590-0494$ 大阪府泉南郡熊取町 2-1010

TEL: (072)451-2456 FAX: (072)451-2620 E-mail: xzshen@ rri.kyoto-u.ac.jp

*** (株)原子力安全システム研究所

$\dagger$ 日本原子力研究開発機構
} 
で代表される通常口径管のスラグ流と異なり、大 小様々な形状の気泡が間欠的に密集して流れる 流動状態として観察される。本研究では先ず、

Shen らが提案した気泡流からスラグ流までの連 続的な変化に対応するドリフトフラックスモデ ル相関式[2]に基づいた界面抗力モデルを構築し た。さらに、定常一次元二流体モデルの数值解析 を行って、大口径管内気液二相流の気泡流からス ラグ流までの流動様式遷移現象を再現すると共 に実験検証し、流動様式遷移により流れ方向ボイ ド率が $N$ 字型に変化することを確認して、その現 象のメカニズムに関連して気泡の挙動を明らか にした。

\section{2. 基礎方程式系と数值解析}

本研究は垂直長尺大口径管内低流速気液二相 流を対象としている。先ず、本研究で使用する定 常一次元二流体モデルの基礎方程式、構成方程式、 数值解析方法を整理しておく。

\section{1 定常一次元二流体モデル}

定常一次元二流体モデルの基礎方程式は以下 のように表される[3-5]。

$$
\begin{gathered}
\alpha \rho_{G} U_{G}=G_{G} \\
(1-\alpha) \rho_{L} U_{L}=G_{L} \\
\alpha \rho_{G} U_{G} \frac{d U_{G}}{d z}=-\alpha \frac{d P}{d z}-\alpha \rho_{G} g+M_{i G}-M_{w G} \\
(1-\alpha) \rho_{L} U_{L} \frac{d U_{L}}{d z}=-(1-\alpha) \frac{d P}{d z}-(1-\alpha) \rho_{L} g+M_{i L}-M_{w L} \\
\rho_{G}=\rho_{G}(P) \\
\rho_{L}=\rho_{L}(P)
\end{gathered}
$$

ここで各記号は、 $\alpha$ : ボイド率、 $G$ : 質量流束、 $\rho$ : 密度、 $U$ : 相平均速度、 $P$ : 圧力（ここでは相間 圧力差が無視できるとしている)、 $z$ : 流れ方向位 置、 $M_{i}$ : 相間運動量輸送量 $\left(M_{i G}+M_{i L}=0\right) 、 M_{w}$ : 管壁と各相間の摩擦、 $g$ : 重力加速度を表す。ま た、添字の $G 、 L$ は各々気相、液相を表す。

気泡流からチャーン流の範囲では気相が壁と 直接接触することはほとんどない。そこで、気相 と壁間の摩擦がないと仮定し、気相の壁面摩擦 $M_{w G}$ を以下の式で与える。

$$
M_{w G}=0
$$

液相の壁面摩擦 $M_{w L}$ に対して、Tomiyama ら [3]
は次式を推薦した。

$$
M_{w L}=\frac{\lambda_{L}}{2 D} \rho_{L} j_{L}^{2} \Phi^{2}
$$

ここで $j_{L}\left(=(1-\alpha) U_{L}\right)$ は見掛けの流速である。 $\lambda_{L}$ と $\Phi^{2}$ はそれぞれ摩擦係数と二相摩擦増倍係数で あり、以下の式を採用する。

$$
\begin{aligned}
& \lambda_{L}=0.3164\left(\frac{j_{L} D}{v_{L}}\right)^{-1 / 4} \\
& \Phi^{2}=(1-\alpha)^{-1.75}
\end{aligned}
$$

ここで $\nu$ は動粘性係数である。なお低流速では、 壁面摩擦の寄与は大きくないと考えられる。

\section{2 界面抗力モデル}

二流体モデル相間運動量輸送量 $\left(M_{i G}\right.$ と $\left.M_{i L}\right)$ は、定常成分である相間摩擦力（即ち界面抗力 $\left.M_{D}\right)$ と非定常成分である Basset 力 $\left(M_{B}\right)$ や仮想 質量力 $\left(M_{V M}\right)$ により表される。

$$
M_{i L}=-M_{i G}=M_{B}+M_{V M}+M_{D}
$$

Basset 力は粘性力に対する加速度の効果を表す が、通常無視している。仮想質量力についての評 価は、臨界流などのような急激な過渡変化の解析 において有効であるという報告[6]もあるが、現 時点では確立しているとはいえない。従って、こ こでは、仮想質量力も無視すれば、相間運動量輸 送項は相間の相互作用を記述する界面抗力 $M_{D}$ で 構成する。

界面抗力の取り扱いの方法として、流れの幾何 学的形態に基づき界面積濃度 $a_{i}$ と抗力係数 $C_{D}$ の 構成式を組み合わせて表現する取り扱いとドリ フト速度を利用して表現する取り扱いの 2 通り がある。前者では界面抗力 $M_{D}$ が界面積濃度 $a_{i}$ と 抗力係数 $C_{D}$ を用いて次式のように表される。

$$
M_{D}=\frac{1}{8} a_{i} C_{D} \rho_{L}\left(U_{G}-U_{L}\right)\left|U_{G}-U_{L}\right|
$$

界面積濃度 $a_{i}$ と抗力係数 $C_{D}$ の構成式は流動様式 ごとに流れの形態を考慮して別々の取り扱いが なされている[6]。後者では先ず十分発達した定常 1 次元気液二相流の運動量保存式 (式(3) と (4)) から次式のような界面抗力 $M_{D}$ を得る。

$$
M_{D}=\alpha(1-\alpha)\left(\rho_{L}-\rho_{G}\right) g-(1-\alpha) M_{w G}+\alpha M_{w F}
$$

次に、上式を、導出された運動量保存式から独立 
させるために、ドリフトフラックスモデルに基づ く相関式を連立させて、独立な界面抗力相関式を 作る。

Andersen \& Chu [7]と Tomiyama ら[8]はドリフ 卜速度 $V_{G J}$ の組み合わせ $\left(V_{G J}\left|V_{G J}\right|\right) /\left(V_{G J}\left|V_{G J}\right|\right)$ を式 (13)の右辺に掛け、分子の $V_{G J}$ を平均ドリフト速

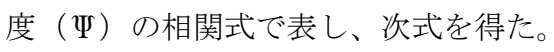

$$
\begin{gathered}
M_{D}=\frac{\Psi|\Psi|\left\{\alpha(1-\alpha)\left(\rho_{L}-\rho_{G}\right) g-(1-\alpha) M_{w G}+\alpha M_{w F}\right\}}{V_{G J}\left|V_{G J}\right|} \\
\Psi=\left(1-C_{0} \alpha\right) U_{G}-C_{0}(1-\alpha) U_{L}
\end{gathered}
$$

ここで $C_{0}$ は分布定数である。

Tomiyama ら[3]は相間相対速度 $U_{R}$ の組み合わ せ $\left(U_{R}\left|U_{R}\right|\right) /\left(U_{R} \mid U_{R}\right)$ を式(13)の右辺に掛け、分子の $U_{R}$ を定義式 $U_{G}-U_{L}$ で表し、次式を得る。

$$
\begin{gathered}
M_{D}=\left\{\alpha(1-\alpha)\left(\rho_{L}-\rho_{G}\right) g-(1-\alpha) M_{w G}+\alpha M_{w F}\right\} \\
\times \frac{\left(U_{G}-U_{L}\right)\left|U_{G}-U_{L}\right|}{U_{R}\left|U_{R}\right|} \\
U_{R}=\frac{V_{G J}+\left(C_{0}-1\right) U_{L}}{1-C_{0} \alpha}
\end{gathered}
$$

得られた界面抗力の式(14)と(16)において、関数 形が異なるが両者は同じ值を与える[3]。

式(15) と(17)にある分布定数 $C_{0}$ とドリフト速度 $V_{G J}$ は管内局所ボイド率分布と局所流速分布の影 響及び相間相対速度の影響を考慮して取り扱う 必要がある。通常、分布定数 $C_{0}$ とドリフト速度 $V_{G J}$ の構成式は流動様式に依存するとしているが、 流動様式遷移過程が界面抗力、分布定数 $C_{0}$ 及び ドリフト速度 $V_{G J}$ に及ぼす影響は考慮していない。 そのような取り扱いは流動様式遷移が短い流動 距離で短時間で発生する比較的小口径の管内気 液二相流に適用できる。しかし、第 4 章に示す実 験結果の通り、大口径管内気液二相流においては、 流動様式遷移が比較的長い流動時間と流れ方向 の広い流動範囲にわたって発生し、配管径サイズ の大気泡の形成と発達も観察されるので、この遷 移流動領域は大口径管内気液二相流においては 重要かつ特徴的な流動領域であり、それらの流動 遷移過程が界面抗力、分布定数 $C_{0}$ 及びドリフト 速度 $V_{G J}$ に及ぼす影響が無視できないと考えられ る。

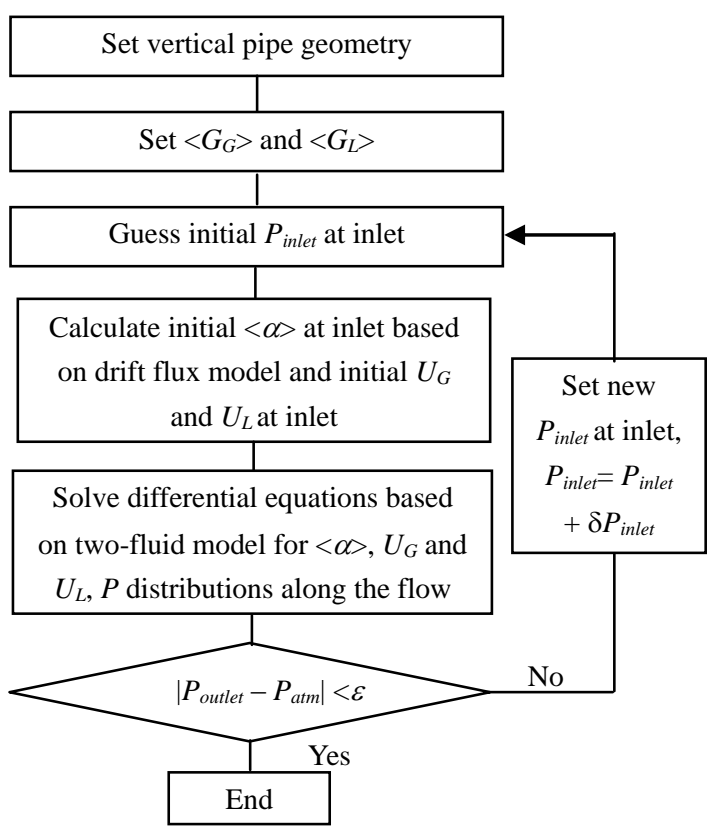

Fig. 1 Flow chart of numerical calculation.

大口径管内気液二相流の流れ方向に沿って気 泡流からスラグ流までの流動様式遷移に伴い、半 径方向のボイド率分布は平坦な壁ピークから平 坦なコアピークの形に変化する[9, 10]。Shen ら[2] はShawkatらのダブルセンサープローブと熱線流 速計の実験データ[11]と Shen らのフォーセンサ ープローブ、熱線流速計及び差圧計の実験データ [10, 12]に基づき、気泡流からスラグ流まで連続的 に変化する大口径管内流動に対して、以下の分布 定数 $C_{0}$ とドリフト速度 $V_{G J}$ の構成式を提案した。

$C_{0}=1$

$$
\begin{gathered}
V_{G J}=\frac{1}{2}\left(V_{G J-S}+V_{G J-B}\right)+\frac{1}{\pi}\left(V_{G J-S}-V_{G J-B}\right) \\
\times \operatorname{arctg}\left\{A \times\left(\frac{j_{G}}{j_{L}+j_{G}}-B\right)\right\}
\end{gathered}
$$

ここで

$$
\begin{aligned}
& V_{G J-B}=\sqrt{2}\left(\frac{g \sigma\left(\rho_{L}-\rho_{G}\right)}{\rho_{L}^{2}}\right)^{1 / 4} \\
& V_{G J-S}=0.52 \sqrt{\frac{D g\left(\rho_{L}-\rho_{G}\right)}{\rho_{L}}} \\
& A=6.72\left(j_{L}^{+}\right)^{2}-34.00\left(j_{L}^{+}\right)+69.94
\end{aligned}
$$




$$
\begin{gathered}
B=0.0851\left(j_{L}^{+}\right)^{2}-0.414\left(j_{L}^{+}\right)+0.955 \\
j_{L}^{+}=\frac{j_{L}}{\left(\frac{\sigma g\left(\rho_{L}-\rho_{G}\right)}{\rho_{L}^{2}}\right)^{1 / 4}}
\end{gathered}
$$

大口径管内の気液二相流の多次元流動特性によ り、ボイド率と気液二相の流速の半径方向の分布 が平坦となり、相分布パラメーター $C_{0}$ が約 1 とな る $\left(\right.$ 式(18))。 $V_{G J-B}$ と $V_{G J-S}$ はそれぞれ気泡流とス ラグ流のドリフト速度である。Hirao らは大口径 管内の気泡流に対して式(20)を推薦した[13]。 Shen らが提案したスラグ流に対する式 (21)は Hirao らの大口径管用スラグ流相関式[13] と一致 している。気泡流からスラグ流まで連続的に変化 するドリフト速度 $V_{G J}$ の構成式(19)は気泡流の式 (20)とスラグ流の式(21)の内挿式である。 $A$ と $B$ はそれぞれ内挿式の増倍率とゼロ点であり、無次 元液相体積流束に関連寸る。分布定数 $C_{0}$ の構成 式(18)及びドリフト速度 $V_{G J}$ の構成式(19)は高 $z / D$

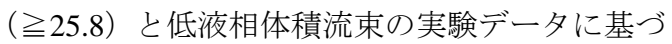
いており、この条件で流れはほぼ平衡に達してお り、異なる気液の混合方法の影響は小さいと考え られる。本研究の数值解析では、分布定数 $C_{0}$ の 構成式(18)及びドリフト速度 $V_{G J}$ の構成式(19)を 用いる。

\section{3 数值計算}

定常一次元二流体モデル（式(1)-(4)）は以下 のように非線形連立常微分方程式の初期值問題 として整理できる。

$$
\begin{aligned}
& \frac{d \alpha}{d z}=\left\{(1-\alpha)\left(M_{D}+\alpha \rho_{G} g\right)\right. \\
& \left.+\left(\alpha-\frac{G_{G} U_{G}}{P}\right)\left[M_{D}-M_{w L}-(1-\alpha) \rho_{L} g\right]\right\} \\
& /\left[\frac{G_{G} U_{G}}{\alpha}(1-\alpha)+\frac{G_{L} U_{L}}{1-\alpha}\left(\alpha-\frac{G_{G} U_{G}}{P}\right)\right] \\
& \frac{d P}{d z}=\left\{\frac{G_{G} U_{G}}{\alpha}\left[M_{D}-M_{w L}-(1-\alpha) \rho_{L} g\right]\right. \\
& \left.-\frac{G_{L} U_{L}}{1-\alpha}\left(M_{D}+\alpha \rho_{G} g\right)\right\} \\
& /\left[\frac{G_{G} U_{G}}{\alpha}(1-\alpha)+\frac{G_{L} U_{L}}{1-\alpha}\left(\alpha-\frac{G_{G} U_{G}}{P}\right)\right]
\end{aligned}
$$

$$
\begin{aligned}
& \frac{d U_{G}}{d z}=-\frac{U_{G}}{P}\left\{\frac{G_{G} U_{G}}{\alpha}\left[M_{D}-M_{w L}-(1-\alpha) \rho_{L} g\right]\right. \\
& \left.-\frac{G_{L} U_{L}}{1-\alpha}\left(M_{D}+\alpha \rho_{G} g\right)\right\} \\
& /\left[\frac{G_{G} U_{G}}{\alpha}(1-\alpha)+\frac{G_{L} U_{L}}{1-\alpha}\left(\alpha-\frac{G_{G} U_{G}}{P}\right)\right] \\
& -\frac{U_{G}}{\alpha}\left\{(1-\alpha)\left(M_{D}+\alpha \rho_{G} g\right)\right. \\
& \left.+\left(\alpha-\frac{G_{G} U_{G}}{P}\right)\left[M_{D}-M_{w L}-(1-\alpha) \rho_{L} g\right]\right\} \\
& /\left[\frac{G_{G} U_{G}}{\alpha}(1-\alpha)+\frac{G_{L} U_{L}}{1-\alpha}\left(\alpha-\frac{G_{G} U_{G}}{P}\right)\right] \\
& \frac{d U_{L}}{d z}=\frac{U_{L}}{1-\alpha}\left\{(1-\alpha)\left(M_{D}+\alpha \rho_{G} g\right)\right. \\
& \left.+\left(\alpha-\frac{G_{G} U_{G}}{P}\right)\left[M_{D}-M_{w L}-(1-\alpha) \rho_{L} g\right]\right\} \\
& /\left[\frac{G_{G} U_{G}}{\alpha}(1-\alpha)+\frac{G_{L} U_{L}}{1-\alpha}\left(\alpha-\frac{G_{G} U_{G}}{P}\right)\right]
\end{aligned}
$$

式(25)-(28)の解は、例えば、ルンゲクッタ数值 積分法などにより求めることができる。Fig. 1 は 配管の寸法と二相流量が与えられた場合、流れ方 向のボイド率、二相の流速及び圧力分布を計算す る手順を示したものである。

\section{3. 垂直長大口径管内気液二相流の実験}

実験装置の概略をFig. 2 に示す。実験装置は試 験部、下部気水混合部、上部気水分離器、ポンプ、 タンクなどからなる。水は循環ポンプにより上部 リザーバーからベンチュリー流量計（2 系統）を 通って気水混合部 (1 系統は気水混合器外部、他 の 1 系統は気水混合器の狭い隙間部）に送られ、 二相流となって試験部を上昇し、上部のリザーバ 一に戻る。空気は、空気圧縮機により一旦蓄圧夕 ンクに貯められ、そこから流量計を通って気水混 合部に送られ、そこで水と混合される。気水混合 部では、狭い間隙の水流中に細孔から空気を噴出 させ、細かな気泡を発生させ水と混合する。大口 径管試験部の内径は $0.2 \mathrm{~m}$ で、高さは $26 \mathrm{~m}$ である。 本実験では Fig. 2 に示しているように入口の圧 力計と 7 台の差圧計により流れ方向の圧力分布 を測定し、実験条件が低流速範囲で、摩擦圧力損 
失が無視できることを考慮して差圧測定結果よ り断面平均ボイド率を次式のように得る。

$$
\alpha=1-\frac{\Delta P_{D P}}{\left(\rho_{L}-\rho_{G}\right) g \Delta z}
$$

ここで $\Delta P_{D P}$ は試験部区間 $\Delta z$ の差圧測定值である。 本実験の液相と気相の流速範囲は $0.050 \mathrm{~m} / \mathrm{s} \leqq$ $j_{L} \leqq 0.311 \mathrm{~m} / \mathrm{s} 、 0.052 \mathrm{Nm} / \mathrm{s} \leqq j_{G} \leqq 0.510 \mathrm{Nm} / \mathrm{s}$ で、平 均ボイド率範囲は $0.011 \leqq \alpha \leqq 0.392$ である。

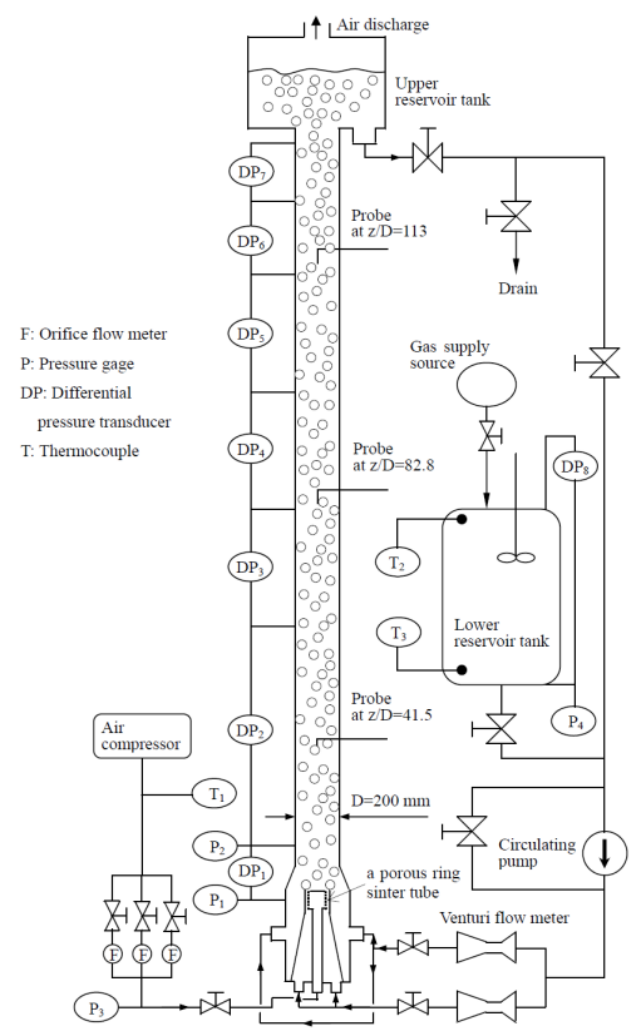

Fig. 2 Schematic of experimental apparatus.

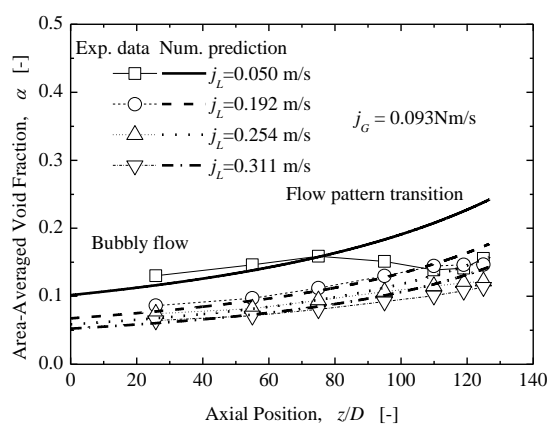

(a) $j_{G}=0.093 \mathrm{Nm} / \mathrm{s}$

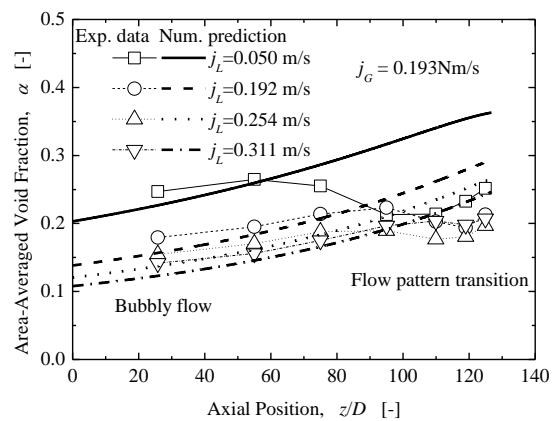

(b) $j_{G}=0.193 \mathrm{Nm} / \mathrm{s}$

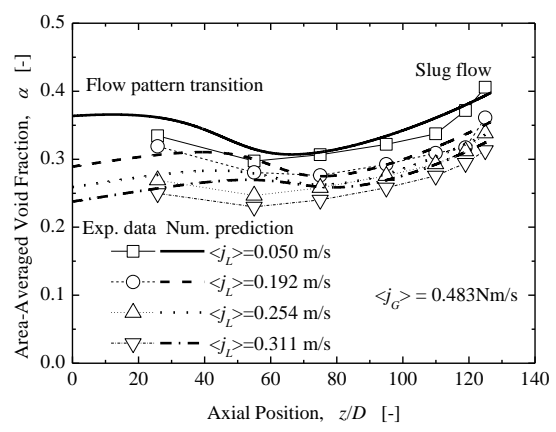

(c) $j_{G}=0.484 \mathrm{Nm} / \mathrm{s}$

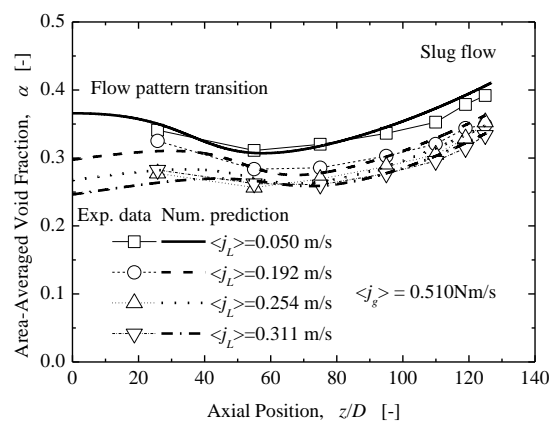

(d) $j_{G}=0.510 \mathrm{Nm} / \mathrm{s}$

Fig. 3 Axial development of void fraction from the measurement of differential pressure gauges and the numerical prediction.

\section{4. 実験と計算の結果及び比較検討}

\section{1 実験結果}

流路断面平均ボイド率の流れ方向分布の測定 結果をFig. 3 に示す。これらの測定結果と実験の 流動観察から以下のようなことが分かる。(1)低 
$j_{G}$ の流動範囲内で、試験部上流の大部分の流動領 域は気泡流となる。気泡流では流れ方向の圧力低 下に伴い、下流に向かってボイド率が増えていく。 $J_{L}$ が小さくなると、気泡の合体と分裂により大き いサイズの気泡が徐々に形成され、相間相対流速 が速くなり、ボイド率が低下していく。(2) 高 $j_{G}$ の流動条件では、試験部の入り口からすぐに大き いサイズの気泡ができ、流れ方向に沿ってそれら の気泡が更に配管径サイズに達するまで成長す る。大気泡の成長に伴い、相間相対速度が速くな り、ボイド率が低下していく。しかし、配管径の 制限により大気泡の先端部分の形状の変化は止 まるため、相間相対速度の増加は止まり、ボイド 率の低下もなくなる。その時点から、流れ方向の 圧力低下により、ボイド率が再び増加傾向に変わ る。(3)サイズが配管径程度で、その先端部分の形 状が一定であるような大気泡を含む管内気液二 相流をスラグ流と定義すれば、大口径管内気泡流 からスラグ流への流動様式遷移が長い流動時間 と広い流動範囲にわたって観察された。また、そ の流動様式遷移に伴い、流れに沿うボイド率の変 化が、気泡流域で増加、遷移流域では減少、そし てスラグ流域で再び増加する $N$ 字型の変化を示 す。

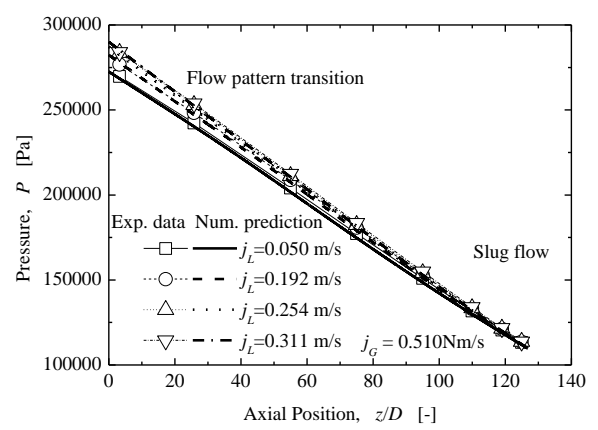

Fig. 4 Predicted axial development of pressure.

\section{2 計算結果及び考察}

Fig. 3(a)、(b)、(c)及び(d)に断面平均ボイド率 の軸方向分布の計算結果を示す。断面平均ボイド 率の計算值は差圧法により測定した流れ方向の ボイド率分布と比較した。両者の平均相対誤差は 10.4\%となる。Fig. 4、5 及び 6 には、それぞれ、 典型的な流動条件 $\left(j_{G}=0.510 \mathrm{Nm} / \mathrm{s}\right)$ に対する圧力、 気相と液相平均流速の計算結果を示す。流れ方向
の圧力分布は差圧法により測定したデータの全 てに対して平均相対誤差 $1.23 \%$ で予測できる。そ れらの計算結果より以下のことが分かった。

(1) Shen ら[2]のドリフトフラックスモデル相関式 に基づいた界面抗力モデルを用いる数值解析が 大口径管内流れ方向の $N$ 字型ボイド率変化を予 測できる。低気相流速の領域で、ドリフト速度 $V_{G J}$ の内挿構成式(19)が基づくスラグ流がまだ形 成しておらず、 $N$ 字型ボイド率変化の予測精度が 低下する。今後その現象の予測精度を向上するた めに、Shen ら[2]のドリフトフラックスモデル相 関式に対して、低気相流速の領域の補正が必要か もしれない。

（2）実験結果の通りに、気泡流からスラグ流まで の流動様式遷移が長い流動時間と広い流動範囲 にわたって発生している。

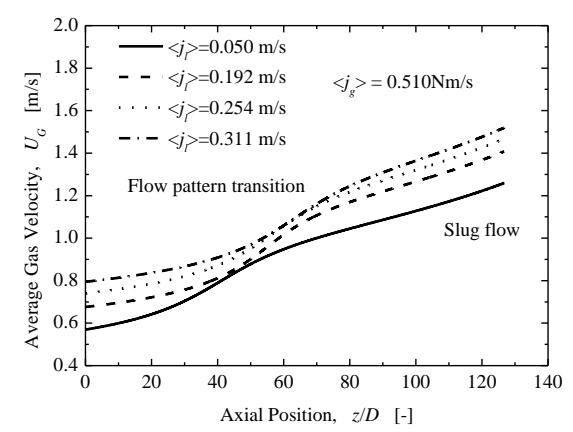

Fig. 5 Predicted axial development of average gas velocity.

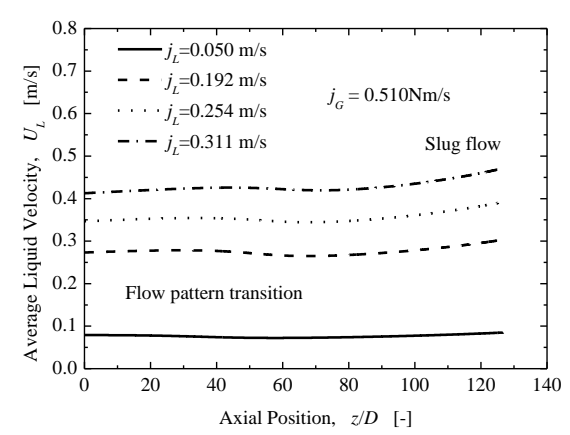

Fig. 6 Predicted axial development of average liquid velocity.

(3) 大口径管内気泡流からスラグ流までの流動様 式の遷移が発生する時は、流れ方向のボイド率が 
急激に減少し、気相流速（Fig. 5 の $z / D=30-60 ）$ が急速に増大し、液相流速（Fig. 6 の $z / D=30-60)$ がわずかに減少する傾向になっている。気泡流か らスラグ流まで流れ方向全体のボイド率が増加 一減少一再増加の $N$ 字型のように変化している。 気泡流からスラグ流までの流動様式の遷移領域 で大気泡の形成と発達がこれらの現象の原因と 考えられる。

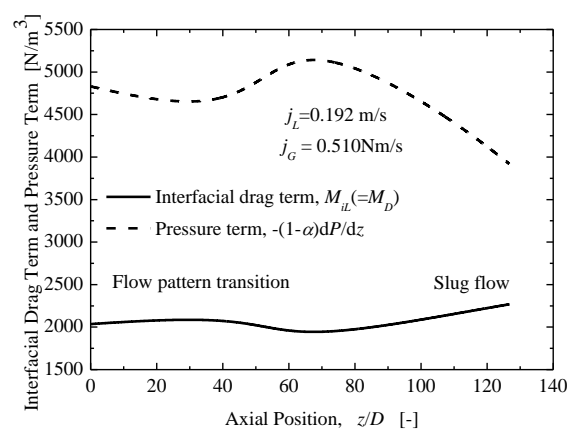

Fig. 7 Predicted axial development of interfacial drag term and pressure term.

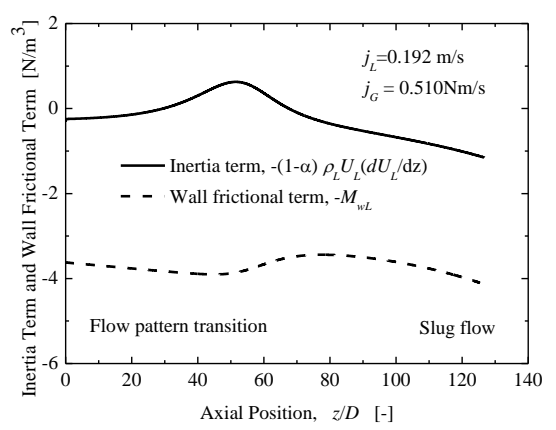

Fig. 8 Predicted axial development of liquid phase inertia term and wall frictional term.

大口径管内において気泡流からスラグ流まで の流動様式遷移が発生する時、液相の運動量保存 式（式(4)）にある界面抗力項、慣性力項、壁面摩 擦力項、圧力項及び重力項の軸方向変化を調べる ため、典型的な流動条件 $\left(j_{L}=0.192 \mathrm{~m} / \mathrm{s}, j_{G}=0.510\right.$ $\mathrm{m} / \mathrm{s}$ ) に対して数值計算を行い、界面抗力項、圧 力項、慣性力項、壁面摩擦力項の結果を Fig. 7、 8 のように示す。重力項の結果は Fig. 3(d)に示す 断面平均ボイド率の変化から推知できる。その結 果より以下のことが分かった。(1) 気泡流とスラ
グ流では、流れ方向に沿って界面抗力が次第に増 加するが、流動様式の遷移領域では、断面平均ボ イド率の大きな減少により界面抗力も流れ方向 に沿って減少した。強制循環の気液二相流では、 界面抗力は重力と駆動圧力に次ぐ重要なもので ある。(2) 流速変化に誘起される慣性力項は、流 動様式の遷移に伴って一時、流れ方向に正になっ た。それの原因は大気泡の形成と発達によって液 相流速がわずかに減少したことによる。また、慣 性力項は他の項より無視できるほど小さくなっ た。(3) 液相に対しては、圧力項と界面抗力項が 駆動力となり、重力項と壁面摩擦項が抵抗となる。 圧力項と重力項はボイド率に関連するため、流動 様式の遷移領域で前者は増大し、後者は減少した。

\section{5. 結 言}

本研究では、垂直長尺大口径管内低流速気液二 相流に対して実験研究と数值解析を行い、以下の 結論を得た。

(1) 気泡流からスラグ流までの流動様式遷移が大 気泡の形成と発達により長い流動時間と流れ方 向の広い流動範囲にわたって発生した。その遷移 領域では相間相対流速の増大によって流路断面 平均ボイド率が減少するため、流れ方向全体の流 路断面平均ボイド率が「気泡流で増加 $\rightarrow$ 遷移領域

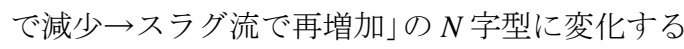
ことを確認した。

（2）大口径管内の流動様式遷移現象を予測するた め、Shen ら[2]が提案した気泡流からスラグ流ま での変化に対応するドリフトフラックスモデル 相関式に基づいて、界面抗力モデルを提案した。 (3) 定常一次元二流体モデルにその界面抗力モデ ルを取り込んで実施した数值解析が、流動様式遷 移に伴う流れ方向ボイド率の $N$ 字型変化を予測 できることを確認した。

(4) 界面抗力は重力と駆動圧力に次ぐ重要なもの である。気泡流からスラグ流までの流動様式に沿 って、界面抗力は気泡流で次第に増大し、流動様 式の遷移領域で減少し、スラグ流で再び増大した。

\section{謝 辞}

本研究は、平成 20 22 年度文部科学省 科学研 究費補助金（基盤研究（C）20560774）の助成を 受けた。本実験の遂行にあたり、日本原子力研究 開発機構の大津嵋氏と錦沢友俊氏及び原子力工 
ンジニアリング株式会社の山田グループの協力

を得た。ここに記して感謝の意を表する。

\section{Nomenclature}

$a_{i} \quad$ : interfacial area concentration

$[1 / \mathrm{m}]$

$C_{D} \quad$ : drag coefficient

$C_{0} \quad$ : distribution parameter

$[-]$

$D \quad$ : pipe diameter

[m]

$G \quad$ : mass flux

$g \quad$ : gravitational acceleration

$\left[\mathrm{kg} /\left(\mathrm{m}^{2} \mathrm{~s}\right)\right]$
$\left[\mathrm{m} / \mathrm{s}^{2}\right]$

$j_{G} \quad$ : superficial velocity of gas phase

$[\mathrm{m} / \mathrm{s}]$

$j_{L} \quad$ : superficial velocity of liquid phase $\quad[\mathrm{m} / \mathrm{s}]$

$P \quad$ : pressure

$M_{B} \quad$ : Basset force

$M_{D} \quad$ : interfacial drag

$M_{i} \quad$ : interfacial momentum

$M_{V M}$ : virtual mass force

$M_{w} \quad$ : momentum loss at wall

$U \quad$ : velocity

$U_{R} \quad$ : relative velocity between phases

$[\mathrm{Pa}]$

$\left[\mathrm{N} / \mathrm{m}^{3}\right]$

$\left[\mathrm{N} / \mathrm{m}^{3}\right]$

$\left[\mathrm{N} / \mathrm{m}^{3}\right]$

$\left[\mathrm{N} / \mathrm{m}^{3}\right]$

$\left[\mathrm{N} / \mathrm{m}^{3}\right]$

$[\mathrm{m} / \mathrm{s}]$

$[\mathrm{m} / \mathrm{s}]$

$V_{G J} \quad$ : drift velocity

$V_{G J-B}:$ drift velocity for bubbly flow

$[\mathrm{m} / \mathrm{s}]$

$[\mathrm{m} / \mathrm{s}]$

$V_{G J-S}:$ drift velocity for slug flow

$z \quad$ : height

$[\mathrm{m} / \mathrm{s}]$

[m]

\section{Greek letters}

$\alpha \quad$ : void fraction

$\Delta P_{D P} \quad$ : differential pressure(DP) by DP meter [Pa]

$\Phi \quad$ : two-phase frictional multiplier $\quad[-]$

$\lambda \quad$ : frictional coefficient $[-]$

$v_{L} \quad:$ kinematic viscosity of liquid phase $\left[\mathrm{m}^{2} / \mathrm{s}\right]$

$\rho \quad:$ density $\quad\left[\mathrm{kg} / \mathrm{m}^{3}\right]$

$\Psi \quad$ : parameter using the average drift velocity correlation

$[\mathrm{m} / \mathrm{s}]$

\section{Subscripts}

$G \quad$ : gas phase

$L \quad$ : liquid phase

\section{参考文献}

[1] Okawa, T., Yoneda, K. and Yoshioka, Y., New Interfacial Drag Force Model Including Effect of Bubble Wake, (I) - Model Development for Steam-Water Bubbly Flow in Large-Diameter Pipes, Journal of Nuclear Science and Technology, Vol. 35(12), 895-904 (1998).

[2] Shen, X., Mishima, K. and Nakamura, H., Flow-induced void fraction transition phenomenon in two-phase flow, Proc. 8th Int.
Conf. on Nuclear Engineer (ICONE18), CD-ROM, Paper No. ICONE18-29630 (2010).

[3] Tomiyama, A., Furutani, N. and Sakaguchi, T., Numerical Stability of the One-Dimensional One-Pressure Steady Two-Fluid Model, Transactions of the Japan Society of Mechanical Engineers, Series B, Vol. 59(560), 1071-1078 (1993).

[4] Lahey, Jr, R., Cheng, L., Drew, D. and Flatherty, J., The Effect of Virtual Mass on the Numerical Stability of Accelerating Two-Phase Flow, Int. J. Multiph. Flow, Vol. 6(4), 281-294 (1980).

[5] Wallis, G. B., One-Dimensional Two-Phase Flow, McGraw-Hill, New York (1969).

[6] Thermal Hydraulics Division, Atomic Energy Society of Japan ed., Numerical Analysis for Liquid-Gas Two-Phase Flow, 76-110, Asakura Publishing Co. Ltd., Tokyo (1993).

[7] Andersen, J. G. M. and Chu, K. H., BWR Refill-Reflood program task 4.7-Constitutive relations for shear and heat transfer for the BWR version of TRAC, NUREG CR2134, EPRI NP-1582 (1981).

[8] Tomiyama, A., Minagawa, H. and Sakaguchi, T., Derivation of Constitutive Equations for Interfacial Momentum Transfer Required for the Analyses of Gas-Liquid-Solid Three-Phase Flow with a One-Dimensional Three-Fluid Model, Transactions of the Japan Society of Mechanical Engineers, Series B, Vol. 57(536), 1239-1245 (1991).

[9] Shawkat, M., Ching, C. Y. and Shoukri, M., Bubble and Liquid Turbulence Characteristics of Bubbly Flow in a Large Diameter Vertical Pipe, Int. J. Multiph. Flow, Vol. 34(8), 767-785 (2008).

[10] Shen, X., Mishima, K. and Nakamura, H., I Measurement of Two-Phase Flow in a Vertical Large Diameter Pipe Using Hot-Film Anemometer, Japanese Journal of Multiphase Flow, Vol. 23(5), 605-613 (2010).

[11] Shawkat, M., Ching, C. Y., Shoukri, M., Bubble and liquid turbulence characteristics of bubbly flow in a large diameter vertical pipe. Int. J. Multiphase Flow, Vol. 34(8), 767-785 (2008).

[12] Shen, X., Matsui, R., Mishima, K., Nakamura, H., Distribution parameter and drift velocity for two-phase flow in a large diameter pipe. Nuclear Engineering and Design, Vol. 240(12), 3991-4000 (2010).

[13] Hirao, Y., Kawanishi, K., Tsuge, A., Kohriyama, T., Experimental study on drift-flux correlation formulas for two-phase flow in large diameter tubes, Proc. 2nd International Topical Meeting on Nuclear Power Plant Thermal Hydraulics and Operations, 1/88-1/94 (1986). 